\title{
Improving Recovery of Narrow Channel Oilfield with Applications of Borehole-seism Integration Technique
}

\author{
Guanghui Sheng
}

\author{
No.5 Production Plant, Daqing Oil Field, China
}

Keywords: combination of well and seismic, reservoir description, remaining oil distribution

\begin{abstract}
In block A channel sand bodies spread in small scale; the drilling rate is low; level of well control is low; under the current condition of well pattern, the accuracy sand body prediction is low; the accuracy of fault recognition is low; the injection and production relationship of single sand body is not perfect; the control degree of water flooding in low; the degree of reserve recovery is low; the effect of development is not good. After the carrying out of find reservoir description based on seismic and well logs, the accuracy of structure based on well seismic- combination improves. With the application of well-seismic combination and multidisciplinary reservoir research, analysis of the residual oil, guidance of well location choosing, injection production system adjustment and oil expanding adjustment achieve good results. In this paper, we take A block as an example, introduce the application of well seismic combination and improve the oil recovery rate and the effect to develop the narrow channel
\end{abstract}

\section{The basic feathers in Block $A$}

Block A lies in the north of an anticlinal-structural reservoir, the oil-bearing area is $57 \mathrm{~km}^{2}$, and geological reserves is $3714 \times 10^{4}$ t. Formation dip angle is not large in both wings, with $3.5^{\circ}$ in the western wing and $3^{\circ}$ in the eastern wing. It has an about north south axial structure.fault throw is $0.5 \mathrm{~m} \sim 64.9 \mathrm{~m}$, horizontally stretching distance is $0.2 \mathrm{~km} \sim 5.7 \mathrm{~km}$. The north of Block A is divided into five fault blocks of different sizes.each block stucture is developed ${ }^{[1]}$.

Block A is a continental river - delta depositional heterogeneity of oil fields, gives priority to with development of narrow channel, whose width is between $200-600 \mathrm{~m}$. Reservoir gives priority to with yaojia formations group I P I of the cretaceous reservoir, SII pinch out from the south of oil reservoir T14. P I reservoir is comprised of 3 sands tone groups and 13 sedimentary units, and sand body development scale with $1 \sim 2 \mathrm{~m}$ single sandstone thickness is small, who has discontinuous strip and scattered distribution ${ }^{[2]}$.

\section{The main problems in Block $A$}

Block A went into operation in1980, it has experienced infill adjustment well and Compensatory adjustment wells. The low waterflood control degree, low recoveryt and poor development effect are the main problems in Block A. Compared with other Blocks, waterflood control degree in Block A is $64.2 \%$ ( Table 2-1-1),which is $13.5 \%$ less than than in Block $\mathrm{C}$ when they have similar development condition.It could be seen in the table of producing degree of different block, producing degree of Block $A$ is the highest(Table 2-1-2). However,when composite water cut is more than $90.0 \%$, recovery degree is low, only $23.03 \%$. 


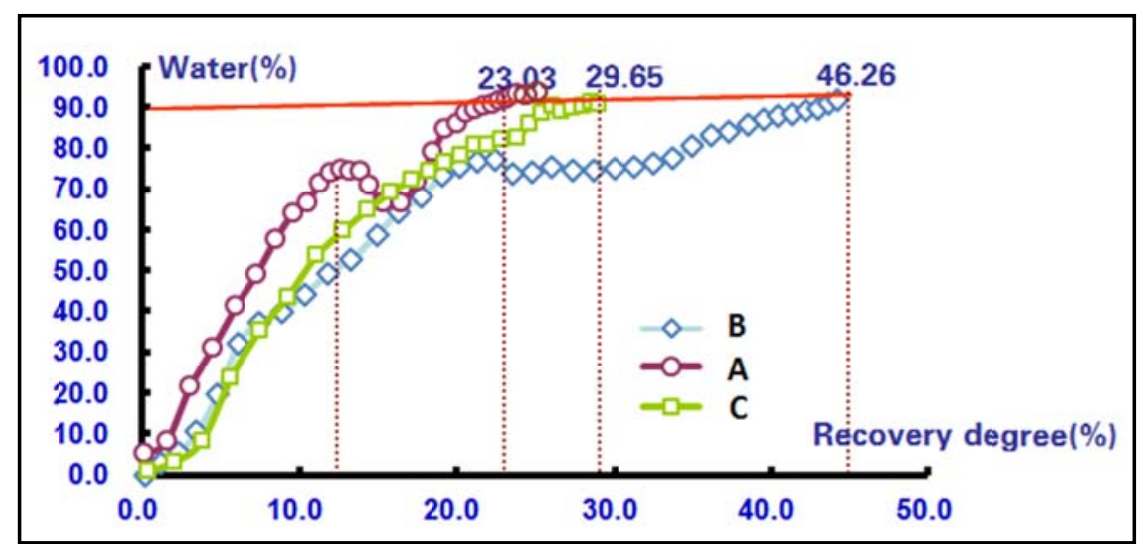

Fig. 2-1-1 Curve of relationship of water cut and recovery in different blocks

Table 2-1-1 Waterflooding control degree of different development blocks

\begin{tabular}{|c|c|c|c|c|c|c|c|c|c|c|c|c|}
\hline \multirow{3}{*}{$\begin{array}{c}\text { Blo } \\
\text { ck }\end{array}$} & \multicolumn{3}{|c|}{$\begin{array}{l}\text { Single direction } \\
\text { connection }(\%)\end{array}$} & \multicolumn{3}{|c|}{$\begin{array}{l}\text { The two sides to connect } \\
(\%)\end{array}$} & \multicolumn{3}{|c|}{$\begin{array}{l}\text { Three or more } \\
\text { directions }(\%)\end{array}$} & \multicolumn{3}{|c|}{$\begin{array}{c}\text { Effective connection } \\
(\%)\end{array}$} \\
\hline & $\begin{array}{l}\text { The } \\
\text { layer } \\
\text { numbe }\end{array}$ & \begin{tabular}{|} 
sandsto \\
ne \\
thicknes
\end{tabular} & effecti & $\begin{array}{l}\text { The } \\
\text { layer }\end{array}$ & $\begin{array}{l}\text { sandsto } \\
\text { ne } \\
\text { thicknes }\end{array}$ & $\begin{array}{l}\text { effectiv } \\
\text { ethickne }\end{array}$ & $\begin{array}{l}\text { The } \\
\text { layer }\end{array}$ & $\begin{array}{l}\text { sandsto } \\
\text { ne } \\
\text { thicknes }\end{array}$ & effect & $\begin{array}{l}\text { The layer } \\
\text { number }\end{array}$ & $\begin{array}{c}\text { sandst } \\
\text { one } \\
\text { thickn }\end{array}$ & \begin{tabular}{|c|} 
effecti \\
ve \\
thickn
\end{tabular} \\
\hline & r & $\mathrm{S}$ & & & $\mathrm{S}$ & & & $\mathrm{S}$ & ckness & & ess & ess \\
\hline $\mathrm{B}$ & 14.7 & 22.4 & 17.8 & 25.2 & 30.2 & 28.8 & 52.4 & 39.8 & 44.2 & 92.3 & 92.4 & 90.8 \\
\hline $\mathrm{A}$ & 35.8 & 38.2 & 30.0 & 18.5 & 25.0 & 23.0 & 5.7 & 10.6 & 11.2 & 60.0 & 73.7 & 64.2 \\
\hline $\mathrm{C}$ & 38.1 & 38.7 & 35.0 & 21.5 & 26.2 & 27.2 & 8.6 & 13.7 & 15.5 & 68.2 & 78.6 & \begin{tabular}{|l|}
77.7 \\
\end{tabular} \\
\hline
\end{tabular}

Table 2-1-2 the use situation of reservoir of different development blocks

\begin{tabular}{|c|c|c|c|c|c|c|c|c|c|}
\hline \multirow[b]{2}{*}{$\begin{array}{c}\text { Blo } \\
\text { ck }\end{array}$} & \multicolumn{3}{|c|}{ The use of proportion $(\%)$} & \multicolumn{3}{|c|}{ bad use ratio $(\%)$} & \multicolumn{3}{|c|}{ good use proportion $(\%)$} \\
\hline & $\begin{array}{c}\text { The layer } \\
\text { number }\end{array}$ & \begin{tabular}{|c} 
sandsto \\
ne \\
thicknes \\
s
\end{tabular} & $\begin{array}{l}\text { effective th } \\
\text { ickness }\end{array}$ & \begin{tabular}{|c|} 
The \\
layer \\
number
\end{tabular} & $\begin{array}{l}\text { sandstone } \\
\text { thickness }\end{array}$ & $\begin{array}{l}\text { effective } \mathrm{t} \\
\text { hickness }\end{array}$ & $\begin{array}{l}\text { The layer } \\
\text { number }\end{array}$ & $\begin{array}{l}\text { sandstone } \\
\text { thickness }\end{array}$ & $\begin{array}{l}\text { effective } t \\
\text { hickness }\end{array}$ \\
\hline $\mathrm{B}$ & 68.2 & 76.7 & 82.8 & 24.4 & 19.3 & 15.9 & 43.8 & 57.4 & 66.9 \\
\hline A & 80.5 & 88.7 & 94.3 & 19.7 & 12.7 & 9.6 & 60.8 & 76 & 84.7 \\
\hline $\mathrm{C}$ & 77.6 & 87.1 & 91.3 & 24.9 & 15.7 & 14.1 & 52.7 & 71.4 & 77.2 \\
\hline
\end{tabular}

The mainly reasons have two aspects: one is that fault dip is big, well spacing density is low, most breakpoints lies in not the oil formation, only $17.39 \%$ penetrated breakpoints are in the oil formation. It is not good to control the distribution of the faults in the oil formation. The other is that a oil layer in Block $\mathrm{A}$ is mainly inner-front surfacies sediment, develops in small scale, the drilling rate of channel sand body is low, only $22.45 \%$. At the same time, the accuracy prediction of sand bodies between wells is low.

\section{Fine geologic knowledge was got after application of combination of well with seismic to exploit A oil block}

Since 2008,X oil-field has deployedChangyuan development seismic work, structure interpretation and application of fine reservoir description based on combination of well with seismic to excavatemaximumpotential of the old seismic data.In order to enhance the precision of reservoir recognitionfurther, the development technicist has worked on structure, fine description of reservoin on A blockwell seismic combination. Well combined with recognition and reservoir, the fine reservoir description techniques of old and high water cut oilfield has deepen to guide the residual oil exploitation effectively. 


\subsection{Geological awareness was enhanced by combination of well with seismic \\ 3.1.1The precision of structural fault was enhaced}

There was 40 faults in A block before,but 127 faults were confirmed by combination of well with seismic.as the faults changed,the number ofsmall fault block was increased,from five to eight.Also,local favorable structural was found on the edge ofoilfield, which would be explored rolling extension.

\subsubsection{Reservoir description was enhaced}

Reservoir description of small channels sand was carried out based on combination of well with seismicdring 2010-2011 in A block, by which the channel sand boundary continuity was more accurate so the precision of description was enhanced. theprecision of description of small channels sand increased from $77.2 \%$ to $86.1 \%$.

\subsubsection{The distribution of oil and water was more accurate,whichcound guide well deployment of outside enlarge}

Apply the result of three-dimensional structure modeling based on combination of well with seismic,research was carried out on the original understanding of the oil-water boundary line new explain faults or tectonic lines. Three methods such as Regional reservoir section、Small layers of oil and statistical analysis has been used on oil/water interface calibration for different fault block respectively, oil-water boundary description was more accurate, the oil-water distribution was been re-recognized and $5.2 \mathrm{Km} 2$ potential of outside enlarge was found.

\subsection{Analysis of remaining-oil distribution}

Dring 2011-2012, the new results of structure understanding was put into the multidisciplinary oil reservoir research, which enhanced the precision of remaining-oil distribution, and which guided the foundation of three-dimensional structure modeling based on combination of well with seismic in block A. multidisciplinary reservoir was studied based on the results of structural modeling,which could improve the coincidence rate of digifax water fitting further.also, it could implemented the four quantification, they are quantification of single layer remaining oil, quantification of macroscopic residual oil, quantification of single well layered injection-production condition,quantification of the whole layered injection-production condition.

\subsection{The effect of measure}

After the analysis of remaining-oil distribution,we know that remaining-oil distribution existed in different forms in different parts of the block. The sound effect has been got by taken different extract method according to different parts of the remaining oil.Since $2009,46.0742 \times 10^{4} \mathrm{t}$ recoverable reserves has been increased by placed 66 outside enlarge wells, 77 additional wells ,10 oil wells turning to injection, 10 wells profile controlled,9 wells plugged.Also,thewaterflooding control degree has been considerably improved, with sandstone increased by $7.5 \%$,effective thickness increased by $7.0 \%$. Production decline and comprehensive water cut has been effectively controlled, which contributed to quadratic stability during high water-cut stage, and which also provided a thought of effective development for similar oil fields.

Table 3-3-1 statistical table of the change ofwaterflooding control degree

\begin{tabular}{|c|c|c|c|c|c|c|c|c|c|c|c|c|}
\hline \multirow{3}{*}{$\begin{array}{l}\text { Categor } \\
y\end{array}$} & \multicolumn{3}{|c|}{$\begin{array}{l}\text { Single direction } \\
\text { connecting }(\%)\end{array}$} & \multicolumn{3}{|c|}{$\begin{array}{l}\text { Double direction } \\
\text { connecting }(\%)\end{array}$} & \multicolumn{3}{|c|}{$\begin{array}{l}\text { Three or more } \\
\text { directionconnecting }(\%\end{array}$} & \multicolumn{3}{|c|}{$\begin{array}{l}\text { Total of effective } \\
\text { thickness connection } \\
(\%)\end{array}$} \\
\hline & lay & & & & & & laye & sandstor & effectiv & laye & & fff \\
\hline & & & b & $r$ & 1 & e & $\mathrm{r}$ & e & & & & \\
\hline & & & & & & & 5.7 & & & 60 & 73 & 64.2 \\
\hline A & 28.8 & & 6 & 23. & & & 17.2 & & & 69.7 & 31.3 & 71.3 \\
\hline lue & -7.0 & -6.1 & -1.4 & 5.3 & $T$ & 2.3 & 11.5 & 9. & & 9.7 & 7.5 & 7.0 \\
\hline
\end{tabular}

3.4 The water-flooding characteristic curve showed that the recovery has been obviously improved

$\mathrm{A}$ and $\mathrm{B}$ water-flooding characteristic curves were drove using exploitation data of A block(Fig 3-5-1,Fig3-5-2). The fitting result showed that B water-flooding characteristic curve was more suitable for evaluation of the district. The B water-flooding characteristic curve predicted the 
ultimate recovery of $22.67 \%$ before the redeployment while the ultimate recovery of $25.78 \%$ after the redeployment, New recoverable reserves increased by $38.35 \times 10^{4} \mathrm{t}$, the average single well recoverable reserves $4676.8 \mathrm{t}$.

Fig3-4-1A water-flooding characteristic linear regression figure

Fig3-4-2B water-flooding characteristic linear regression figure

Table 3-4-1 recovery changes in block A

\begin{tabular}{|c|c|c|c|}
\hline curve types & $\begin{array}{c}\text { recovery before } \\
\text { redeployment } \\
(\%)\end{array}$ & $\begin{array}{c}\text { recovery } \\
\text { afterredeployment } \\
(\%)\end{array}$ & $\begin{array}{c}\text { increase amplitude } \\
(\%)\end{array}$ \\
\hline $\begin{array}{c}\text { A water-flooding } \\
\text { characteristic curve }\end{array}$ & 17.50 & 22.24 & 4.74 \\
\hline $\begin{array}{c}\text { B water-flooding } \\
\text { characteristic curve }\end{array}$ & 22.40 & 25.90 & 3.50 \\
\hline
\end{tabular}

\section{Conclusion}

(1)To Narrow Channel Oilfield with Fault breakpoints main distribution low reservoir area ,Borehole-seism Integration Technique is more accordant to practice and helpful to guideoilfield exploitation andconstruction for Explaining the fault data.

(2) To Narrow Channel Oilfield, deepening the cognition of geologic and distribution

of remaining oilto perfect injection-production relationshipspecificly is the key toimprove the oilfield development effect.

\section{References}

[1]Wei linYan, ZhengchenLi, YangSu.The study of Daqingchangyuan log interpretation permeability variation law at different times $[\mathrm{J}]$. Journal ofDaQingPetroleum Geology and Development, 2002,17 (5) : 54-58

[2] LeiLiu, YanqingMeng,ChunhuiMa. JingAn oilfield remaining oil distribution law and the research of tapping production potential of remaining oil .Petrochemical Industry Applications. 2014, 30 (4) : 6-15

[3] Kaichun Yu, YanZhu ,YanMeng. Application and describe ofBorehole-seism Integration Technique in Taibei oilfield development zone.Journal of Northeast Petroleum University, 2012, 36 (4) : 49-53

[4]ChunhuaXu,JiagenHou, Yuzhen Yangetc.Use the method of micro structure analysis to fine characterization of reservoir [J]. Journal of Geology, 2011, 35 (4) : 369-374

[5]Jingye Lin, YingTong,XinjiangWang. The Research of Daqingchangyuan sandstone structure reservoir oil-water interface control factor [J]. Journal of Petroleum Exploration in China, 2007 (3) : $13-16$ 